\title{
CORRELATION OF GRAIN CHARACTERS IN RICE (ORYZA SATIVA L.)
}

\author{
A.K.M. GOLAM SARWAR", M.A. ALI and M.A. KARIM \\ Department of Crop Botany, Bangladesh Agricultural University, Mymensing $/ 2-2202$, \\ Bangladesh.
}

(Received: 29 October 1997; accepted: 02 October 1998)

\begin{abstract}
Morphological characters of rice grains (Oryza sativa L.) taking four cultivars each from each of modern and traditional cultivars, grown in Boro season were studied. The length, breadth and thickness of grain (unhulled grain), length and breadth of kernel (hulled grain), embryo length, embryo-endosperm ratio and 1000 -grain weight, and their interrelationship were investigated. There were significant differences regarding values of all parameters except glain thickness and embryo length among the cultivars. Significant correlations between grain length to kernel length $\left(r=0.9655^{\circ}\right)$, grain breadth to grain thickness $\left(r=0.8938^{*}\right)$, kernel breadth ( $\left.r=0.9783^{*}\right)$ and 1000 -grain weight ( $r=0.7727 \%$ ) were found. Embryo length did not show any relationship between othes. characteristics of grain or kernel.
\end{abstract}

Key words: Embryo, grain character, kernel, rice,

\section{INTRODUCTION}

Grain shape and size are the most important factors which influence yield and quality of rice (Oryza sativa L.). Morphological characters and their effects on grain quality and yield have been studied by many researchers. ${ }^{1-7}$ The grain characteristics of rice cultivars in Bangladesh have not been thoroughly investigated. Therefore, the present investigation was undertaken to study the morphological characters of rice grain (unhulled grain) and kernel (hulled grain) and their interrelationship.

\section{METHODS AND MATERIALS}

Eight cultivars of rice of two types i.e. modern viz., BR7, BR29, Iratom24, and BR3, and traditional viz. Hapa, Kaliboro, Kachliboro and Madhabshail-boro, were used for morphological investigation of the grains which were grown in the Boro season (December to May) in Bangladesh. Thirty unhulled grains were collected from the top of 3 panicles (10 from each) and used for measurement of each cultivar. The grains were hulled afterwards and again used for measurement of different parameters. The values for 6 characters i.e. length $(\mathrm{mm})$, breadth $(\mathrm{mm})$ and thickness $(\mathrm{mm})$ of grain, length $(\mathrm{mm})$ and breadth $(\mathrm{mm})$ of kernel and embryo length $(\mathrm{mm})$ were measured with a slide-caliper. The length breadth ratio of grain was calculated from length of grain divided by breadth of grain. The weight of 1000-grains from primary and secondary branches were measured by digital balance. Embryo-endosperm ratio was calculated as ratio of embryo and kernel length.

\footnotetext{
"Corresponding author.
} 
The collected data were analysed following ANOVA-technique and means were separated by Duncun's Multiple Range Test (DMRT) using MSTAT computer package. The correlation value among different parameters were calculated from the mean values using Casio fx-100s VPAM scientific calculator.

\section{RESULTS AND DISCUSSION}

\section{Length of grain}

Data representing the length of the grains (Table 1) showed that BR7 and Kachliboro had significantly the longest $(9.81 \mathrm{~mm})$ and the shortest grain $(7.49$ $\mathrm{mm}$ ) respectively whereas the others gave intermediate values.

The present results indicated that the modern cultivars possessed longer grain and higher yield potential which supported the previous results reported by Yoshida ${ }^{.}$Sarwar ${ }^{9}$ also reported that modern cultivars (BR7, BR29, Iratom24. and BR3) produced higher yield compared to traditional cultivars (Hapa, Kaliboro, Kachliboro and Madhabshail boro). This difference in length of grain might be due to the genetic make-up of the cultivars. ${ }^{10}$

\section{Breadth of grain}

Data representing breadth of the grain (Table 1) revealed significant variation among the cultivars. Madhabshail-boro had the highest breadth ( $3.55 \mathrm{~mm}$ ) fo]lowed by BR3 $(3.17 \mathrm{~mm})$ and Iratom-24 $(3.15 \mathrm{~mm})$ while BR7 and BR29 had lower grain breadth ( $2.38 \mathrm{~mm}$ and $2.58 \mathrm{~mm}$, respectively). All the other cultivars had intermediate values.

Madhabshail-boro being the traditional cultivar possessed wider grain and lower yield potential which was in full agreement with the earlier results. ${ }^{8.9}$ This difference in breadth of grain might be due to the genetic make-up of the cultivars. ${ }^{10}$

\section{Thickness of grain}

Data representing thickness of the grain (Table 1) showed that the cultivar Madhabshail-boro had the thickest grain $(2.34 \mathrm{~mm})$ followed by BR3 $(2.07 \mathrm{~mm})$ while BR7 had the thinnest one $(1.82 \mathrm{~mm})$. All other cultivars had intermediate values.

These results indicated that the yield potential of rice cultivars might not be related to grain thickness. Breadth of grain was strong. y correlated with grain thickness $\left(r=0.8938^{* * k}\right)$. Similar result was observed by Jun." 


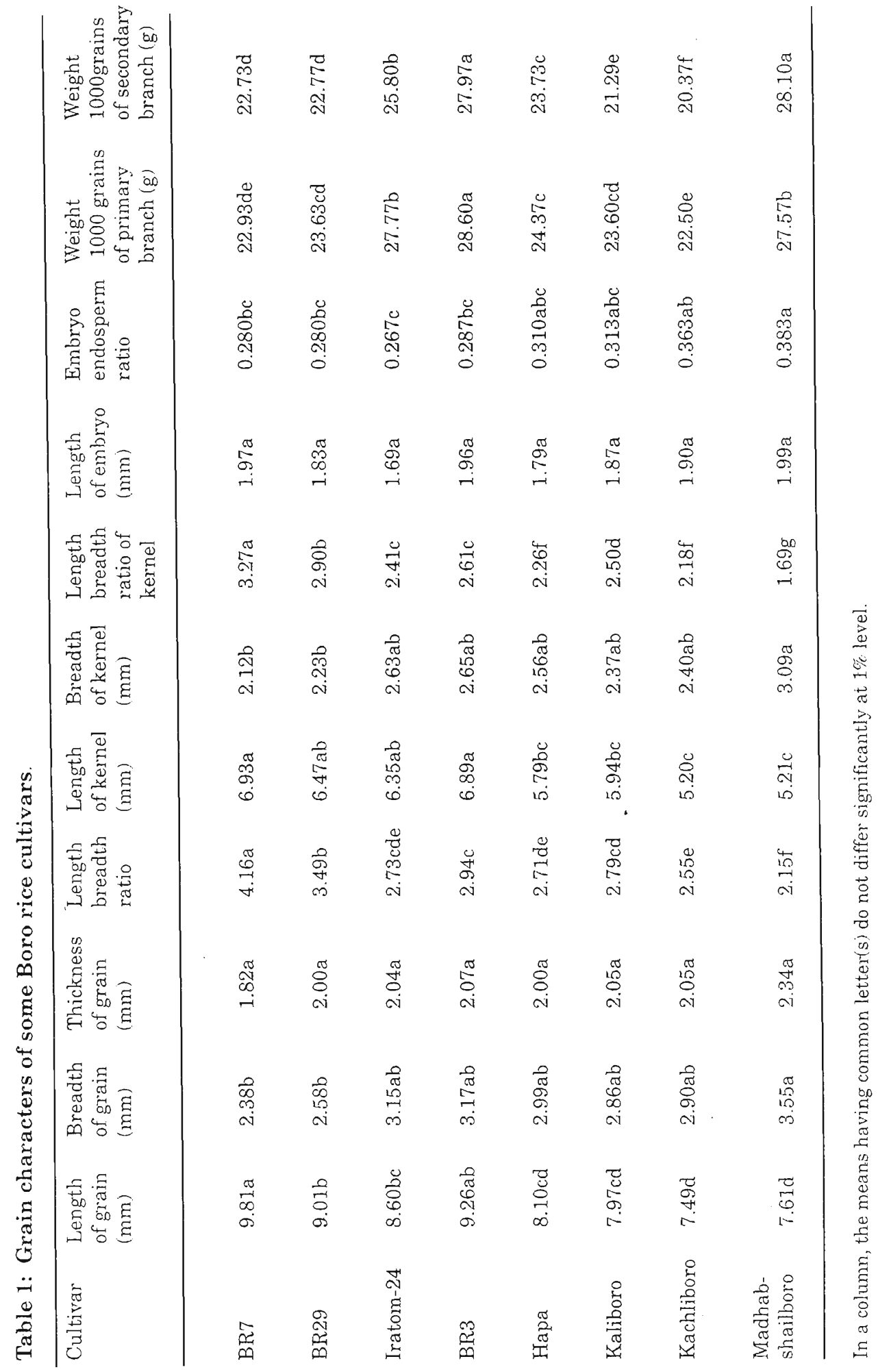




\section{Length-Breadth $(\mathrm{L} / \mathrm{B})$ ratio of grain}

The data representing the $\mathrm{L} / \mathrm{B}$ ratio (Table 1 ) showed that $\mathrm{BR} 7$ possessed the highest L/B ratio (4.16) followed by BR29 (3.49) and Madhabshail-boro possessed the lowest (2.15) ratio. All other cultivars showed the intermediate position.

BR7 and BR29 possessed L/B ratio of more than 3 which indicated that these were of slender grains and other cultivars were with long grains. ${ }^{1}$ Iratom 24, Hapa and Madhabshail-boro although possessed relatively long grains showed lower L/B ratio because of higher breadth. Grain length and breadth had strong positive and negative correlation $\left(\mathrm{r}=0.8698^{* * 1 *},-0.887^{* *: *}\right)$ respectively with $\mathrm{L} / \mathrm{B}$ ratio of grain. This result supported the earlier observation." The grain thickness also had strong negative correlation $\left(x=-0.8465^{* * *}\right)$ with $\mathrm{L} / \mathrm{B}$ ratio of grain.

\section{Length of kernel}

Data representing kernel length (Table 2) revealed that BR7 and BR3 had significantly higher kernel length $(6.93 \mathrm{~mm}$ and $6.89 \mathrm{~mm}$, respectively) compared to the rest. Kachliboro and Madhabshail-boro possessed the lower length $(5.20 \mathrm{~mm}$ and $5.21 \mathrm{~mm}$, respectively) and the others showed intermediate length. There was a strong correlation $\left(r=0.9655^{\text {: }}\right.$ ) between grain length and the kerne] length.

Table 2: Correlation co-efficients among the different grain and kernel characters.

\begin{tabular}{|c|c|c|c|c|c|c|c|}
\hline Characters & $\begin{array}{l}\text { Grain } \\
\text { Brea- } \\
\text { clth }\end{array}$ & $\begin{array}{l}\text { Grain } \\
\text { Thick- } \\
\text { ness }\end{array}$ & $\begin{array}{l}\text { Length } \\
\text { breadth } \\
\text { ratio of } \\
\text { grain }\end{array}$ & $\begin{array}{l}\text { Kernel } \\
\text { length }\end{array}$ & $\begin{array}{l}\text { Kernel } \\
\text { breadth }\end{array}$ & $\begin{array}{l}\text { Embryo } \\
\text { length }\end{array}$ & $\begin{array}{l}1000 \\
\text { grain } \\
\text { weight }\end{array}$ \\
\hline Grain length & $-0.5696^{\mathrm{NS}}$ & $-0.6658^{\mathrm{NS}}$ & 0.8698 & $0.9655^{3 *}$ & $-0.5072^{\mathrm{NS}}$ & $-0.0952^{\mathrm{NS}}$ & $0.066^{\mathrm{NSS}}$ \\
\hline Grain breadth & & $0.8938^{m:}$ & $-0.8837 \%$ & $-0.5054^{\mathrm{NS}}$ & $0.9783^{\prime}$ & $0.0345^{\mathrm{NS}}$ & $0.7727 \%$ \\
\hline Grain thickness & & & $-0.8465^{* *}$ & $-0.6464^{N s}$ & $0.6115^{\mathrm{NS}}$ & $0.2105^{\mathrm{Ns}}$ & $0.5607^{\mathrm{NS}}$ \\
\hline Kernel length & & & & & & $-0.0299^{\mathrm{Ns}}$ & $0.1456^{\mathrm{NS}}$ \\
\hline Kernel breadth & & & & & & $0.1186^{\mathrm{NS}}$ & $0.7680^{\prime \prime}$ \\
\hline
\end{tabular}

NS $=$ Not significant at $5 \%$ level

$\because \quad=\quad$ Significant at $5 \%$ level

: $=$ Significant at $1 \%$ level 


\section{Breadth of kernel}

Data on kernel breadth (Table 1) showed that the cultivar Madhabshail-boro had the highest kernel breadth $(3.09 \mathrm{~mm})$ followed by BR3 $(2.65 \mathrm{~mm})$ and BR7 possessed the lowest breadth $(2.12 \mathrm{~mm})$. Other cultivars had the intermediate status. There was a strong correlation $\left(r=0.9783^{* k: k}\right)$ between grain and kernel breadth.

\section{Length-Breadth $(\mathrm{L} / \mathrm{B})$ ratio of kernel}

Data representing $\mathrm{L} / \mathrm{B}$ ratio of kernel (Table 1 ) revealed that $\mathrm{BR} 7$ possessed the highest L/B value (3.27) followed by BR29 (2.90). Madhabshail-boro possessed the lowest $\mathrm{L} / \mathrm{B}$ value (1.69) and other cultivars had the intermediate values.

According to USDA scale for milled rice BR7 and Madhabshail-boro were slender and bold type respectively and other cultivars were medium type. ${ }^{12}$ Bari el al. ${ }^{1: 3}$ also reported that linear relationship existed between increased L/B ratio and better quality of grains.

\section{Length of embryo}

Embryo length (Table 1) was different among the cultivars. Madhabshail-boro had the largest embryo length $(1.99 \mathrm{~mm})$ followed by BR7 $(1.97 \mathrm{~mm})$. Iratom 24. had the smallest embryo $(1.69 \mathrm{~mm})$ when other cultivars possessed the intermediate values.

Though the modern cultivars possessed larger length of kernel than those of traditional cultivars, the embryo length did not show any special trend and the embryo length did not depend either on length, breadth and thickness of the grain or on length and breadth of the kernel (Table 2).

\section{Embryo-Endosperm ratio}

The data representing the embryo-endosperm ratio (Table 1) showed that Madhabshail-boro and Iratom-24 possessed the highest $(0.383)$ and the lowest embryo-endosperm ratio (0.267) respectively. Other cultivars had the intermediate status.

The embryo-endosperm ratio varied from 0.383 to 0.267 which was in full agreement with that of Grist. ${ }^{2}$ 


\section{0-grain weight}

Data on 1000-grain weight presented in Table 1 revealed that there was no clear difference between traditional and modern type of rice but showed significant differences among the cultivars. Weight of 1000-grains obtained from primary branches of BR3 possessed the highest weight (28.60) followed by Iratom-24. $(27.77 \mathrm{~g})$. Kachliboro possessed the lowest weight ( $22.50 \mathrm{~g})$. It was also observed that the weight of 1000-grain from the primary branches was higher than those of secondary branches in all cultivars except Madhabshail-boro (Table 1). Similar resul.t was obtained by $A n^{1}$. Breadth of grain had a strong correlation $\left(r=0.7727^{*}\right)$ with 1000-grain weight while there were positive but not significant correlation with grain length and thickness (Table 2). $\mathrm{Jun}^{3}$ and $\mathrm{Lin}^{6}$ reported similar observations. Katayama ${ }^{4}$ also reported that 1000 -grain weight was directly related to grain size and might be used as selection and classification characters.

\section{References}

1. Ahn J.K. (1986). Physiological factors affecting grain filling in rice. Ph.D. Thesis. University of the Philippines. Los Banos, Philippines.

2. Grist D.H. (1959). Rice. Longmans Green and Co. Ltd., London.

3. Jun B.T. (1985). Studies on the inheritance of grain size and shape in. rice (Oryza sativa L.). Research Report of the Rural Development Admin. istration, Korea Repablic, Crops 27(2): 1-27.

4. Katayama T.C. (1988). Morphological characters of the cultivated rice grain of Burma IV. Memoirs of faculty of Agriculture, Kagoshima University 24: 21-36.

5. Lim S.J., Kim H.H. \& Lee S.K. (1991). Estimated genetics statistics and varietal differences for the grain shape in rice. Research Report of the Rural Development Administration, Rice 33(1): 1-9.

6. Lin T.F. (1988). Study on the relationship between the morphology characteristics of the grain and grain chalkiness in rice. Bulletine Taichung District Agricultural Improvement Station No. 20: 30-40.

7. Sharma K.K., Ahmad T. \& Baruah D.K. (1990). Grain characteristics of some aromatic rice varieties of aman. International Rice Research Newsletter 15(1): 13-14

8. Yoshida S. (1981). Fundamentals of rice crop science. 269p. International Rice Research Institute. Los Banos, Philippines. 
9. Sarwar A.K.M.G. (1997). Morpho-physiological studies of some selected rice varieties during boro season. M.S. Thesis. Department of Crop Botany, Bangladesh Agricultural University, Mymensingh.p.89.

10. BRRI. (1995). Adhunic Dhaner Chash. Bangladesh Rice Research Institute, Joydebpur, Gazipur. 52p.

11. Katayama T.C. (1993). In: Science of the rice plant, Vol. I, Morphology. (Eds. T. Matsuo \& K. Hoshikawa) pp. 41-49. Food and Agricultural Policy Research Center, Tokyo, Japan.

12. Chang T.T. \& Bardenas E.A. (1965). The Morphology and varietal characteristics of the rice plant. Technical Bulletine 4:21. Internationa] Rice Research Institute, Los Banos, Philippines.

13. Bari G., Mustafa G., Soomro A.M. \& Baloch A.W. (1981). In: Agronomic and quality traits of some elite rice genotype. (1Eds. F. M. Abbasi, M.A. Saga, M. Akram \& M. Ashraf) Pakistan Journal of Science and Industrial Research 38: 348-350. 